\title{
НАЦІОНАЛЬНО-КУЛЬТУРНА СПЕЦИФІКА ГЕНДЕРНО МАРКОВАНИХ ФРАЗЕОЛОГІЗМІВ 3 КОМПОНЕНТОМ-ЗООНІМОМ У СУЧАСНІЙ НІМЕЦЬКІЙ МОВІ
}

\author{
Марія Лозицька \\ Східноєвропейський національний університет імені Лесі Українки, \\ просп. Волі, 13, м. Луиььк, Украӥна, 43000 \\ mariia.losytska@gmail.com
}

\begin{abstract}
Статтю присвячено вивченню національно-культурної специфіки гендерно маркованих фразеологізмів 3 компонентом-зоонімом. Метою дослідження $є$ аналіз основних аспектів характеристики статей крізь семантику компонента-зооніма у складі фразеологізму. Завдяки методу лінгвокультурного аналізу виявлено, що гендерно марковані фразеологізми з компонентом-зоонімом у німецькій мові вказують на осіб чоловічої чи жіночої статей та імплікують певну характеристику останніх, яка залежить від поглядів даної культури на тварину, назва якої входить до компонентного складу фразеологізму. Шляхом використання методу суцільної вибірки, семантичного та компонентного аналізів, визначено, що гендерно марковані фразеологізми з компонентом-зоонімом характеризують чоловіка та жінку за трьома основними категоріями: зовнішність, розумові здібності та риси характеру. Для характеристики привабливої жіночої зовнішності найчастіше використовуються компоненти-зооніми, що належать до класу комах. При означенні зовнішності чоловіка за допомогою фразеологічних одиниць 3 компонентом-зоонімом використовуються тварини з класу ссавців та прослідковується принцип подібності, а не символічності, як при характеристиці жіночої вроди. Для оцінки розумових здібностей обох статей у німецькій фразеології використовуються, зазвичай, домашні тварини. Компонентами, які називають окремі риси характеру чоловіків та жінок, слугують номінації як диких, так і домашніх тварин, причому негативна конотація таких фразеологічних одиниць переважає.
\end{abstract}

Ключові слова: фразеологічна одиниця, гендерно маркований фразеологізм, зоонім, лінгвокультурна картина світу.

Вступ. Дослідження сучасної лінгвістики спрямовані на розкриття коду нації 3 метою глибшого проникнення у ментальний простір певного народу та прагматизації лінгвокультурної картини світу, яка грунтується на уявленнях національної спільноти про дійсність. Лінгвокультурна дійсність представлена системою концептів (зокрема і культурних) як вагомих психоментальних координат, які вербалізуються у мові. Лінгвокультурна картина світу нації значною мірою відображена у фразеології, зокрема, В. А. Маслова зазначає, що відгуки минулих днів знаходять сьогодні своє відображення в прислів'ях, приказках, фразеологізмах, метафорах, символах культури $[6$, c. 3].

Лозицька М., 2019 
Надзвичайно яскраво лінгвокультурна картина світу, частиною якої є і погляди на чоловіка та жінку, виявляється у гендерно маркованих фразеологізмах з компонентомзоонімом, що і зумовлює актуальність цього дослідження. Під гендерно маркованими фразеологізмами з компонентом-зоонімом ми розуміємо фразеологічні одиниці (ФО), що імплікують семи маскулінності та фемінінності шляхом використання у своїй структурі компонентів, що позначають тваринний світ. Метою розвідки є дослідження фразеологічних одиниць 3 компонентом-зоонімом, у семантиці яких присутня характеристика зовнішності, розумових здібностей і рис характеру, які притаманні чоловічій та жіночій статям у німецькій лінгвокультурній парадигмі. Мета дослідження зумовлює вирішення таких завдань:

1) проаналізувати відповідні гендерно марковані ФО з компонентом-зоонімом;

2) виокремити основні аспекти характеристики зовнішності, розумових здібностей і рис характеру осіб чоловічої та жіночої статей крізь семантику компонента-зооніма у складі фразеологізму;

3) розкрити національно-культурну специфіку компонента-зооніма у складі гендерно маркованих фразеологізмів сучасної німецької мови.

Аналіз останніх досліджень і публікацій. Фразеологічні одиниці з компонентомзоонімом завжди заслуговували уваги дослідників та визначалися як "фразеологічні одиниці з анімалістичним компонентом” (Бойко [1, с. 5]), “фразеологія живої природи”, “зоосемічні фразеологічні одиниці” (Петрова [8, с. 6]), “зоофраземи“ (Мацюк [7]), “зоофразеологія” і “зоофразеологічні одиниці” (Ужченко [10]). Д. В. Ужченко розуміє під зоофразеологізмами "порівняно чітко окреслену семантично й тематично групу стійких надслівних мовних утворень, у складі яких $є$ фауноніми (зооніми) або їх образно-генетичні елементи" [10, с. 129]. Д. Ужченко [10] у своєму дослідженні розкрив їхню семантику в етнокультурному плані.

Дослідження фразеологізмів 3 компонентом-зоонімом здійснюється як у межах однієї мови, так і в порівняльному аспекті з опорою на декілька мов: так, предметами філологічних розвідок ставали компаративні зоонімічні фразеологізми німецької мови [4], зоосемічні фразеологізми як носії національно маркованої вторинної номінації в українській та англійській мовах [9], типологія фразеологізмів з компонентом-фаунонімом в українській мові [2], зооніми як окремі лексичні одиниці та компоненти сталих виразів, їхні функції й переклад з англійської на українську мову [3], функціонування зоосемізмів у фразеологізмах німецької та української мов [5] тощо. Зарубіжні наукові студії зосереджені загалом на порівняльному аналізі фразеотематичної групи фразеологізмів з компонентом-зоонімом у межах двох і більше мов: див., наприклад, М. Бюхлер (російська та італійська мови) [11], Г. Гресіано (німецька і французька) [13], М. Муснер (німецька, французька та італійська мови) [15], Д. Добровольський та Е. Пайрайнен (російська, німецька, англійська, нідерландська, фінська, японська мови, а також нижньонімецький діалект) [12].

Очевидно, що розкриття специфіки семантики у фразеологізмах з компонентомзоонімом сучасної німецької мови сприяє глибшому розумінню національнокультурної картини світу та відображенню сприйняття чоловічої та жіночої статей у світі фауни. 
Методологія дослідження. У процесі аналізу досліджуваних явищ ми послуговувалися комплексним підходом, який і визначив стратегію цієї наукової розвідки. Комплексний підхід виявляється найбільш ефективним, оскільки поєднує різні методи, які слугують для вирішення поставлених завдань.

До опису гендерно маркованих фразеологізмів з компонентом-зоонімом залучено також принцип антропоцентризму, згідно з яким головним чинником, що регламентує розвиток і функціонування фразеологічного фонду мови, є людський фактор. Людина (у нашому випадку чоловік та жінка як окремі носії людських якостей) стає точкою відліку в аналізі гендерно маркованих ФО з компонентом-зоонімом.

Методологічні положення та принципи знаходять своє тактичне втілення в методах дослідження. Будь-який метод лінгвістичного дослідження зумовлений метою, завданнями й аналізованим матеріалом лінгвістичного пошуку. 3 огляду на це у своїй науковій розвідці ми застосовували первинні методи дослідження, що використовуються з метою збирання інформації, вивчення джерел тощо, та вторинні, які $є$ важливими під час опрацювання та аналізу отриманих даних. До первинних методів дослідження належить метод збирання та опрацювання інформації, що особливо актуальний під час дослідження теоретичних джерел; метод лінгвістичного опису й спостереження, суть якого полягає в інвентаризації та систематизації, класифікації та інтерпретації фактів і явищ. Процес інвентаризації за допомогою описового методу здійснювався шляхом суцільної вибірки з лексикографічних джерел. Джерельною базою дослідження послужив фразеологічний онлайн-словник “Lexikon für Redewendungen” [14]. Загалом було проаналізовано 40 ФО, що відповідали критеріям відбору. Критерієм для виокремлення ФО послугували гендерні маркери, для визначення яких ми використовували методи семантичного та компонентного аналізу. Застосування методу семантичного аналізу дало змогу виділити з фразеологічного словника саме ті ФО, що містять гендерні семи значення. Метод компонентного аналізу було застосовано 3 метою виокремлення фразеологізмів з компонентом-зоонімом. Отже, ФО зі структурним компонентом-зоонімом у своєму складі та наявністю гендерних сем значення стали предметом нашого дослідження.

Під час опрпцювання та аналізу відібраних $Ф О$, було застосовано лінгвокультурний аналіз, що розкриває здатність ФО відображувати сучасну культурну самосвідомість народу, яка є основою його ментальності. Застосування цього методу сприяло виявленню способів представлення статей в межах німецької лінгвокультури крізь призму компонента-зооніма, виокремленню культурно маркованих якостей фемінінності та маскулінності.

Результати дослідження та їхнс обгрунтування. 3 огляду на те, що риси тварин переносилися на людину (чоловіка, жінку), у змісті такі ФО мають гендерну забарвленість, а у вираженні - компонент-зоонім, що має відношення до світу фауни, слугує для втілення людських якостей та варіює залежно від лінгвокультури. У фразеологізмах такого плану виявляється своєрідність ментального лексикону кожного народу. Саме тому ФО з компонентом-зоонімом привертають пильну увагу дослідників, бо вони є однією з найбільш численних і внутрішньо різноманітних груп специфічного фразеологічного фонду. 
Фразеологізми з компонентом-зоонімом відображають багатовікові спостереження людини за зовнішнім виглядом і звичками тварин, передають ставлення та сприйняття людьми світу фауни. Компонент-зоонім є носієм тезаурисної інформації про типові риси тварин, їхню поведінку та умови пристосування до навколишнього світу. Гендерно марковані фразеологізми з компонентом-зоонімом у німецькій мові вказують на осіб чоловічої або жіночої статей та імплікують певну характеристику останніх, яка залежить від поглядів цієї культури на тварину, що входить до компонентного складу фразеологізму. У семантиці гендерно маркованих фразеологізмів 3 компонентомзоонімом національна специфіка фіксується у таких категоріях, як зовнішність, розумові здібності та риси характеру.

Відображення специфіки сприйняття жіночої статі найчастіше простежується у таких компонентах: комахи та домашні тварини (зовнішність), домашня птиця (розумові здібності), дикі птахи та плазуни (риси характеру). Характерні ознаки зовнішності особи жіночої статі фіксуються у ФО через протиставлення “гарна - негарна” та за допомогою компонентів-зоонімів, наприклад, eine flotte / süße Biene - eine attraktive Frau [14]; ein flotter/ netter Käfer - eine attraktive Frau, ein reizendes Mädchen [14]. Комахи символізують також дівочу бадьорість і жвавість: eine wilde Hummel - ein ausgelassenes / vergnügtes / ungestümes / aufgewecktes Mädchen [14], оскільки, починаючи з XVII ст., неспокійні, жваві дівчатка порівнюються з джмелем. Подібні ФО з компонентом Käfer/Käferlein відомі ще з XIII ст. Як бачимо, важливу роль для характеристики особи жіночої статі має не лише компонент-зоонім, а й відповідний прикметник у своєму прямому значенні. Яскравим прикладом, що ілюструє роль прикметника у ФО, є вирази eine süße Maus eine attraktive Frau; ein kleines, süßes Mädchen / Baby та eine graue Maus - ein unauffällige/ zurückhaltende Frau (umgangssprachlich) [14]. Прикметникова субституція призводить до утворення антонімічного гендерно маркованого фразеологізму, а компонент Maus/ Mäuschen позначає як привабливу, так і непривабливу жінку. ФО eine Mieze sein - eine attraktive Frau [14] вживається у розмовній мові у значенні “кицька” та $є$ вульгаризмом. Краса жінки представлена в німецькій мові і через компонент Schnecke, де ФО набуває вульгарного відтінку: eine Schnecke angraben / anbaggern - mit einer Frau flirten; sich ein hübsches Mädchen angeln [14]. У світі птахів неприваблива жінка виявляється через компонент Entlein - ein hässliches Entlein - ein Mädchen, das nicht besonders hübsch ist [14], що походить з казки Г.-К. Андерсена “Гидке каченя". Проте фразеологічні одиниці, які б фіксували непривабливість жінки, є малочисельними.

Розумові здібності жінок часто прагматизуються у семантиці фразеологізмів 3 компонентом-зоонімом, де імплікуються зазвичай обмеженість, дурість, недалекість особи, на яку вони вказують. Очевидно, зважаючи на те, що розум та невігластво, на відміну від зовнішності, не одразу стають помітними, компонент-зоонім з таким маркером позначає свійських тварин, за звичками та природою яких люди спостерігали та порівнювали їх з людськими якостями. Зокрема, eine dumme / blöde Kuh, eine dumme Pute, eine dumme Gans, eine blöde / dumme Ziege, ein verrücktes Huhn [14] означають нерозумну особу жіночої статі та вживаються як лайливі слова. Компонент-зоонім Gans асоціюється переважно з галасливою жінкою через подібність поведінки. Компоненти $H u h n$ (курка) та Hahn (півень) вживаються у німецькій мові як жартівливі найменування 
жінки та чоловіка. При цьому компонент Huhn має більш негативну конотацію, а Hahn імплікує вигідне суспільне становище: ein leichtsinniges / dummes / armes / blindes / krankes Huhn [14]. Прикметникова субституція впливає на посилення семантичного значення та конотативного забарвлення фразеологізму.

Жіночі риси характеру експлікуються у семантиці ФО з компонентами Kröte, Backfisch, Elster, Schlange. Tак, eine kleine Kröte-ein kleines, freches Mädchen [14] означає мале нахабне дівчисько. Компонент Kröte (жаба, ропуха) відомий ще з Середньовіччя та використовується стосовно жінки як лайливе слово (alte Kröte). Фразеологізм ein Backfisch sein - junges, übermütiges, unreifes Mädchen [14] також асоціюється 3 юною недосвідченою дівчиною. Цей зворот походить 3 англійської мови: "back fish”, що означає малька, якого під час риболовлі викидали назад у воду. Сорока викликає асоціації із злодійкуватою особою жіночої статі: eine diebische Elster - eine Frau, die viel stiehlt; ein Mädchen, das viel stiehlt [14].

Ще з біблійських часів змія є символом підлості, обману та спокуси. При відтворенні гріхопадіння Адама змія часто зображується з головою жінки, щоб, таким чином, підкреслити взаємозв'язок між гріхом, жіночністю та спокусою. Змія $\epsilon$ небезпечною отруйною твариною, і ці їі риси переносять і на жінку: eine falsche Schlange - eine unaufrichtige, hinterlistige Frau [14]. Як бачимо, фразеологічні одиниці для характеристики жіночої статі орієнтовані на висвітлення негативних рис, що, власне, є закономірним, оскільки негативна конотація через психологічні причини завжди виражена яскравіше.

Характеристика чоловіка за допомогою ФО з компонентом-зоонімом відбувається шляхом використання компонентів, які належать до класу ссавців, що зумовлене домінантною роллю цього класу у тваринному світі. Характерні ознаки зовнішності чоловіка виявляються за допомогою ФО з компонентом-зоонімом крізь асоціації на основі подібності. Зокрема, ein Bulle von Kerl - ein stämmiger, kräftiger Mann [14] вказує на фізичні якості чоловіка, а компонент Bulle (бик) асоціюється із силою та витривалістю. ФО ein Gorilla sein - ein großer, muskulöser Mann [14] також вказує на сильного та витривалого чоловіка. Цікавими в плані характеристики зовнішності осіб чоловічої статі є фразеологізми-антоніми, які являють собою ще й гру слів. У першому словосполученні огрядний чоловічий живіт нагадує пузо єнота та протиставляється міцному пресу з чітко видимими “кубиками”, що асоціюється $з$ дошкою для прання: einen Waschbärbauch haben - als Mann einen etwas dickeren Bauch haben; einen dicken Bauch haben та einen Waschbrettbauch haben - als Mann einen Bauch mit sichtbarer Bauchmuskulatur und wenig Fettgewebe haben [14].

Символом чоловічого невігластва слугує віл: ein Ochse / Hornochse sein - ein dummer / einfältiger / sturer Mann [14]. Етимологічно компонент Ochse походить від староіндогерманської основи $o s, o x$, що мала значення “самець” [14].

Для позначення чоловічих рис характеру вживається компонент Hund. Собака належить до улюблених домашніх тварин німецького народу. Негативного конотативного забарвлення ФО з цим зоонімом надає прикметник: ein scharfer Hund-ein autoritärer / strenger Mann; ein harter Hund - ein strenger / hartgesottener / unnachgiebiger / standhafter Mann; ein krummer Hund - ein Betrüger, ein unehrlicher Mann [14]. Компоненти Hahn/ 
Gockel позначають честолюбство чоловіка: ein alter Gockel - ein eitler alter Mann [14]. Означення похітливості чоловіка виявляється через компонент Bock: ein geiler Bock-ein lüsterner Mann [14]. Світ диких тварин теж слугує для характеристики чоловіків. Так, ein Salonlöwe sein-elegant erscheinender Mann, der sich bei gesellschaftlichen Anlässen gern in den Mittelpunkt stellt und die Aufmerksamkeit der Frauen sucht [14] викликає асоціації 3 левом, королем звірів, хоча ФО вживається злегка зневажливо. Компонент Affe викликає негативні асоціації, оскільки мавпа є своєрідним символом первісної людини, яка ще не пристосована до життя в цивілізованому суспільстві, а тому схильна потакати своїм елементарним інстинктам, ein geleckter Affe-ein eitler / gezierter / blasierter Mann [14]. Компонент Hecht (щука) у німецькій мові первинно вживався на позначення особи, схильної до розбою, вторинність його семантики експлікує винятково маскулінність: ein toller Hecht - ein erfolgreicher Mann; jemand, der wegen seiner Cleverness / Unverfrorenheit bewundert wird [14].

Висновки та перспективи подальших досліджень. Отже, гендерно марковані фразеологізми з компонентом-зоонімом являють собою фразеотематичну групу, що слугує для розкриття фемінінних та маскулінних рис у лінгвокультурній картині світу німецького народу. Характеристики статей у фразеологізмах сучасної німецької мови виявляються у таких категоріях як зовнішність, розумові здібності та риси характеру. Привабливість жінки віддзеркалюється крізь компоненти-зооніми, що належать до класу комах та домашніх тварин: Biene, Käfer, Hummel, Mieze, Schnecke, Entlein тощо. Світ комах характеризує не лише зовнішність жінки, але й є втіленням її слабкості. Маскулінність простежується через принципи подібності та за компонентамизоонімами, що належать до класу ссавців: Bulle, Waschbär. Для оцінки розумових здібностей обох статей у німецькій фразеології використовують зазвичай домашніх тварин, що пояснюється близькістю цих представників фауни до людини та кращим розумінням їхньої вдачі (Kuh, Gans, Pute, Huhn, Ziege, Ochse). Втіленням окремих рис характеру чоловіків та жінок слугують як дикі (Kröte, Fisch, Elster, Schlange, Löwe, Affe, Hecht), так і домашні тварини (Hund, Gockel, Bock), при цьому негативна конотація таких ФО переважає. Перспективним убачається дослідження гендерно маркованих фразеологізмів з компонентом-флоронімом для передавання національнокультурної специфіки сприйняття маскулінності та фемінінності у німецькомовному лінгвокультурному просторі.

\section{СПИСОК ВИКОРИСТАНОї ЛІТЕРАТУРИ}

1. Бойко В. М. Структурно-семантичні особливості фразеологічних одиниць з анімалістичним компонентом / В. М. Бойко // Література та культура Полісся. - Ніжин, 2007. - Вип. 36. - С. 3 - 9. - ISSN 2520-6966.

2. Гребенюк А. В. Типологія фразеологізмів з компонентом-фаунонімом [Електронний peсурс] / А. В. Гребенюк // Філологічні студії. Науковий вісник Криворізького державного педагогічного університету. - 2011. - Вип. 6. - С. 128 - 133. - Режим доступу : http://nbuv.gov.ua/UJRN/PhSt_2011_6_20.

3. Дубравська 3. Р. Зооніми як окремі лексичні одиниці та як компоненти сталих виразів [Електронний ресурс] / 3. Р. Дубравська // Молодий вчений. - № 3.1 (55.1). - Березень, 
2018. - C. 51-54. - Режим доступу : http://molodyvcheny.in.ua/files/journal/2018/3.1/13. pdf.

4. Капніна Г. І. Компаративні фразеологізми із зоонімічним компонентом у німецькій мові [Електронний ресурс] / Г. І. Капніна // Вісник Дніпропетровського університету. - Серія : Мовознавство. - 2013. - Т. 21. - Вип. 19(3). - С. 69 - 72. - Режим доступу : http://movoznavstvo.com.ua/download/pdf/2013_3/12.pdf.

5. Коваленко О. В. Функціонування зоосемізмів у фразеологізмах німецької та української мов / О. В. Коваленко, В. В. Рзаєва // Одеський лінгвістичний вісник. - 2013. Вип. 2. - С. $30-38$.

6. Маслова В. А. Лингвокультурология : учеб. пособие для студ. высш. учеб. Заведений / В. А. Маслова. - М. : Издательский центр “Академия”, 2001. - 208 с.

7. Мацюк 3. С. Аби болото, а жаби будуть... (на матеріалі західнополіської фразеології) / 3. С. Мацюк // Вісник Дніпропетровського університету. - Серія “Мовознавство”. № 11. - 2013. - Вип. 19. - Т. 3. - С. $121-127$.

8. Петрова Н. Д. Фразеотематическое поле зоосемизмов в современном английском языке : автореф. дисс. канд. филол. наук : спец. 10.02.04 “Германские язики” / Н. Д. Петрова. - К, 1983. - 22c.

9. Руснак В. І. Зоосемічні фразеологічні одиниці як носії національно маркованої вторинної номінації [Електронний ресурс] / В. І. Руснак. - Наукові записки Національного університету “Острозька академія”. - Сер. : Філологічна. - 2011. - Вип. 19. С. 329 - 336. - Режим доступу : http://nbuv.gov.ua/UJRN/Nznuoaf_2011_19_53.

10. Ужченко Д. В. : автореф. дис. на здобуття наук. ступеня кандидата філол. наук : спец. 10. 02. 01 "Українська мова" / Ужченко Дмитро Вікторович ; Харківський державний педагогічний університет ім. Г. С. Сковороди. - Харків, 2000.

11. Büchler M. Kontrastive Analyse phraseologischer Einheiten mit Tierbezeichnungen im Russischen und Italienischen / M. Büchler // Europhras'95. Europäische Phraseologie im Vergleich. Gemeinsames Erbe und kulturelle Vielfalt / Eismann W. (Hrgs.). - Bochum. 1998. - S. $67-78$.

12. Dobrovol'skij D., Piirainen E. Symbole in Sprache und Kultur: Studien zur Phraseologie aus kultursemiotischer Perspektive / D. Dobrovol'skij, E. Piirainen. - Bochum : Brockmeyer, 1997. - $485 \mathrm{~S}$.

13. Gréciano G. Zur Aktivität der Phrasemkomponenten. Deutsch-französische Beobachtungen / G. Gréciano // Sprichwörter und Redensarten im interkulturellen Vergleich / Sabban A. (Hrsg.). - Opladen. - S. $66-82$.

14. Lexikon für Redewendungen [Elektronische Ressource]. - Zugriffsmodus : http://www. redensarten-index.de/suche.php.

15. MussnerMarlene SprichwörtermitTierbezeichnungen im Komponentenbestand im Vergleich zwischen den Sprachen Deutsch, Französisch und Italienisch und im Vergleich zu anderen satzwertigen Phraseologismen [Elektronische Ressource] / M. Mussner. - Zugriffsmodus : https://www.academia.edu/3733227/Sprichw\%C3\%B6rter_mit_Tierbezeichnungen im_Komponentenbestand_im_Vergleich_zwischen_den_Sprachen_Deutsch_ Franz\%C3\%B6sisch_und_Italienisch_und_im_Vergleich_zu_anderen_satzwertigen_ Phraseologismen. 


\section{REFERENCES}

1. Boiko V. M. Strukturno-semantychni osoblyvosti frazeolohichnykh odynyts z animalistychnym komponentom [Structural-semantic features of phraseological units with an animalistic component] / V. M. Boiko // Literatura ta kultura Polissia. - Nizhyn, 2007. Vyp. 36. - S. 3 - 9 .

2. Hrebeniuk A. V. Typolohiia frazeolohizmiv z komponentom-faunonimom [The typology of phraseological units with faunic component] / A. V. Grebenyuk // Filolohichni studii. Naukovyi visnyk Kryvorizkoho derzhavnoho pedahohichnogo universytetu. - 2011. Vyp. 6. - S. 128 - 133. - Rezhym dostupu : http://nbuv.gov.ua/UJRN/PhSt_2011_6_20.

3. Dubravska Z. R. Zoonimy yak okremi leksychni odynytsi ta yak komponenty stalykh vyraziv [Zoonims as separate linguistic units and components of idioms] / Z. R. Dubravska // Molodyi vchenyi. - № 3.1 (55.1). - Berezen, 2018. - C. 51 - 54. - Rezhym dostupu : http://molodyvcheny.in.ua/files/journal/2018/3.1/13.pdf.

4. Kapnina H. I. Komparatyvni frazeologizmy iz zoonimichnym komponentom u nimetskii movi [The comparative phraseological units with zoonomic component in German] /H. I. Kapnina // Visnik Dnipropetrovskoho universytetu. - Seriia : Movoznavstvo. - 2013. - T. 21. - Vyp. 19(3). - S. 69 - 72. - Rezhym dostupu : http://movoznavstvo.com.ua/ download/pdf/2013 3/12.pdf.

5. Kovalenko O. V., Rzaieva V. V. Funktsionuvannia zoosemizmiv u frazeolohizmakh nimetskoi ta ukrainskoi mov [Funktioning of zoosemisms in phraseological units in Ukrainian and German] / O. V. Kovalenko, V. V. Rzaieva // Odeskyi lingvistychnyi visnyk. 2013. - Vyp. 2. - S. $30-38$.

6. Maslova V. A. Lingvokulturologiya : ucheb. posobie dlya stud. vyssh. ucheb. zavedeniy [Lingvoculturology] / V. A. Maslova. - M. : Izdatelskiy tsentr "Akademiya", 2001. - 208 s.

7. Matsiuk Z. S. Aby boloto, a zhaby budut... (na materiali zakhidnopoliskoi frazeologii) [We need swamps to have frogs (on the material of Western Polesian phraseology)] / Z. S. Matsyuk // Visnyk Dnipropetrovskoho universytetu. - Seriia "Movoznavstvo". № 11. - 2013. - Vyp. 19. - T. 3. - S. $121-127$.

8. Petrova N. D. Frazeotematicheskoe pole zoosemizmov v sovremennom angliyskom yazyke [Phraseothematic field of zoosemism in modern English]: avtoref. diss... kand. filol. nauk : spets. 10.02.04 "Germanskie yazyki" / N. D. Petrova. - K, 1983. - 22 s.

9. Rusnak V. I. Zoosemichni frazeolohichni odynytsi yak nosii natsionalno markovanoi vtorynnoi nominatsii [Zoosemic phraseological units as means of national marked second nomination] [Elektronnii resurs] / V. I. Rusnak. - Naukovi zapyski Natsionalnoho universytetu "Ostrozka akademiia". - Ser. : Filolohichna. - 2011. - Vyp. 19. - S. 329-336. - Rezhym dostupu : http://nbuv.gov.ua/UJRN/Nznuoaf_2011_19_53.

10. Uzhchenko D. V. Semantyka ukrainskykh zoofrazeolohizmiv v etnokulturnomu vysvitlenni [The Semantics of Ukrainian Zooidioms in the Ethnocultural Aspect] : avtoref. dis. na zdobuttia nauk. stupenia kandydata filol. nauk : spets. 10. 02. 01 "Ukrainska mova" / Uzhchenko Dmytro Viktorovych; Kharkivskyi derzhavnyi pedahohichnyi universytet im. G. S. Skovorody. - Kharkiv, 2000.

11. Büchler M. Kontrastive Analyse phraseologischer Einheiten mit Tierbezeichnungen im Russischen und Italienischen / M. Büchler // Europhras'95. Europäische Phraseologie im Vergleich. Gemeinsames Erbe und kulturelle Vielfalt / Eismann W. (Hrgs.). - Bochum. 1998. - S. $67-78$.

12. Dobrovol'skij D., Piirainen E. Symbole in Sprache und Kultur: Studien zur Phraseologie aus kultursemiotischer Perspektive / D. Dobrovol'skij, E. Piirainen. - Bochum : Brockmeyer, 1997. - 485 S. ISBN 978-3-8196-0487-4, 3-8196-0487-1. 
13. Gréciano G. Zur Aktivität der Phrasemkomponenten. Deutsch-französische Beobachtungen / G. Gréciano // Sprichwörter und Redensarten im interkulturellen Vergleich / Sabban A. (Hrsg.). - Opladen. - S. $66-82$.

14. Lexikon für Redewendungen [Elektronische Ressource]. - Zugriffsmodus : http://www. redensarten-index.de/suche.php.

15. Mussner Marlene Sprichwörter mit Tierbezeichnungen im Komponentenbestand im Vergleich zwischen den Sprachen Deutsch, Französisch und Italienisch und im Vergleich $\mathrm{zu}$ anderen satzwertigen Phraseologismen / M. Mussner [Elektronische Ressource]. - Zugriffsmodus : https://www.academia.edu/3733227/Sprichw\%C3\%B6rter_mit_ Tierbezeichnungen_im_Komponentenbestand_im_Vergleich_zwischen_den_Sprachen_

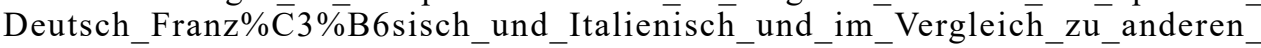
satzwertigen_Phraseologismen

\title{
NATIONAL-CULTURAL FEATURES OF GENDER-MARKED PHRASEOLOGICAL UNITS WITH A ZOONYM COMPONENT IN THE MODERN GERMAN LANGUAGE
}

\author{
Mariia Lozytska \\ Lesya Ukrainka Eastern European National University, \\ prosp. Voli, 13, Lutsk, Ukraine, 43000 \\ mariia.losytska@gmail.com
}

Gender-marked phraseological units with a zoonym component are the focus of the present paper. Its purpose is to analyze the main male and female features in the phraseological units through the prism of the zoonym component. The material of our research is based on the data of German phraseological dictionaries. As main methods of research, semantic and component analyses have been utilized. It has been established that gender-marked phraseological units with a zoonym component in the German language indicate males or females and imply a certain characteristic of them, which depends on the views of the given culture on the animal with the name as part of a given phraseological unit. Gender-marked phraseological units with a zoonym component characterize the man and woman in three main categories: appearance, mental abilities, and features of the character. The appearance of female persons is considered within the opposition "beautiful - ugly". In particular, names of insects combined with a corresponding adjective are often used to denote an attractive woman. The change of the adjective in the phraseological units with the same zoonym component can cause the change in the meaning of this phraseological unit. In the characteristics of the appearance of a man by means of phraseological units with a zoonym component, the principle of similarity is used. In addition, it is not a general assessment of the appearance, but a certain element of it which is characterized. The characteristics of the mental abilities of men and women by means of phraseological units with a zoonym component expresses mainly limitation, stupidity, and the inability of the person who is indicated. The animalistic component, used in phraseological units with such semantics, belongs, as a rule, to domestic animals since people observe such animals and draw parallels between them and humans. In German, phraseological units with a zoonym component are often used both for general assessment of a man and a woman or to distinguish certain features of the character inherent to them. In these phraseological 
units, different zoonym components are used. In some cases, the adjective, which is a component of a unit, determines the meaning of this unit. Consequently, gender-marked phraseological units with a zoonym component serve to reveal feminine and masculine features in the linguistic and cultural picture of the world of Germans. The practical and theoretical significance of our research consists in the possible pedagogical application of the results of the study in language learning to promote better understanding of the culture of native speakers.

Key words: phraseological unit, gender-marked phraseology, zoonym, linguistic-cultural picture of the world. 